\title{
CENTRAL EUROPE AS A TRANSITION ZONE BETWEEN WEST AND EAST
}

\section{KAREN DENNI}

This paper presents various concepts of "Central Europe" that prove the vagueness and ambivalence of the term. It starts by demonstrating the arbitrariness of the "west" and "east" in three geographical examples. This is followed by highlighting historical concepts of Central Europe and some cultural concepts of Eastern dissidents of the 1980s. Finally, some proposals are discussed for considering a symbiosis of the West and East in the transition zone of Central Europe. Keywords: Central Europe, center, transition zone, Friedrich Naumann, dissidents.
Članek predstavlja različne koncepte "srednje Evrope", ki pritrjujejo nejasnosti in amvivalentnosti izraza. Najprej s tremi zemljepisnimi zgledi pokaže na poljubnost "zahoda" in "vzhoda", sledi osvetlitev zgodovinskih konceptov srednje Evrope in nekaj kulturnih konceptov vzhodnih disidentov iz 80. let prejšnjega stoletja. Na koncu je obravnavanih nekaj predlogov za upoštevanje sožitja zahoda in vzhoda na prehodnem območju srednje Evrope.

Ključne besede: srednja Evropa, središče, prehodno območje, Friedrich Naumann, disidenti.

This paper presents various concepts of Central Europe that demonstrate the impossibility of defining its geographical and cultural space. This is not a special problem limited to Central Europe, but applies to Europe as a whole.

From my early childhood on, I have been exposed to classifications of West and East that led me to conclude that these concepts are arbitrary and led me dream of a "between." I clarify my thesis by choosing three geographical stations of my life that document my difficulty in analyzing the concepts of West and East. After a rather personal beginning, I summarize historical concepts of Central Europe before highlighting some cultural concepts of Eastern dissidents of the 1980s. Finally, I conclude with some thoughts on a symbiosis of the West and East.

\section{SOME PERSONAL PERCEPTIONS OF EAST AND WEST}

My native city, Berlin, was the symbol of the hermetical separation of West and East during the Cold War. Politically, West Berlin was counted among the Western states but geographically it was to the East of the East German cities of Dresden and Leipzig. I became aware of the fact that geography by itself is not an important determinant, but what matters is how space is socially and politically constructed. Different interpretations of politics led to different concepts of the "right way," which is only useful as long as the freedom of the other is respected. However, where families were divided against their will, one should 
realize the contingency of the borderline and understand the political interests and reasons for the demarcation. Nonetheless, the propaganda worked very well so that people believed blindly in these ideologies of West and East, which had great consequences for social life. The mental borders persist longer than the material ones. Even today I am often asked if I was born in the west or east side of the city. This is not an innocent question because the West is often associated with the good and fortunate side, and the East with the bad or unlucky side. To avoid this schematization, I answer "in the south of Berlin" - which is, in fact, true.

I left my native city to settle down in France at the same time when the last allies were leaving Berlin. With the end of the Cold War, their presence was no longer justified by military logic. The departure of the soldiers was accompanied by many emotions. There are very few moments in history in which ancient enemies and occupying forces became friends, as happened in West Germany.

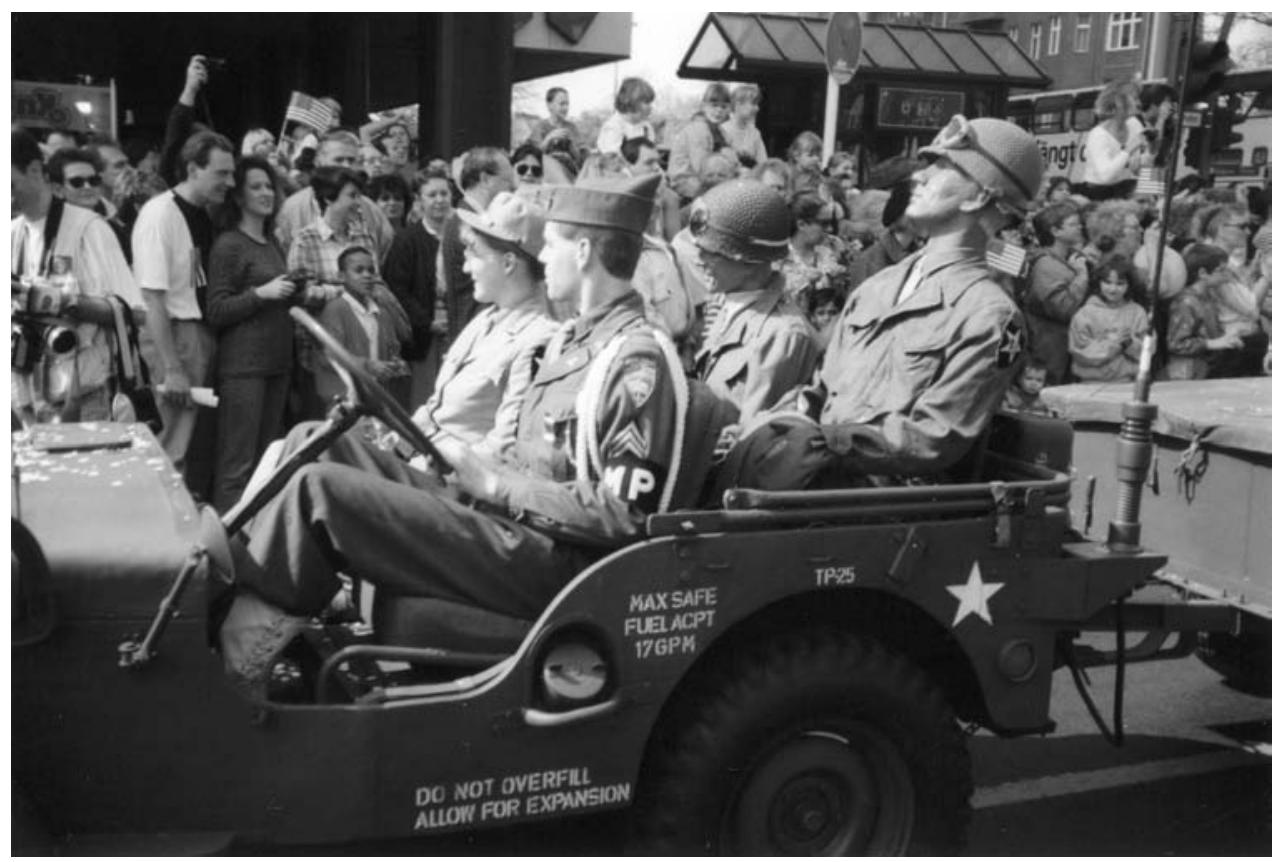

"Americans" in Berlin (photo: K. Denni)

I would not dare to compare the victorious powers of the Second World War to the presence of the Habsburg Monarchy in Central Europe, which met more enthusiasm in some parts than in others, but I understand the nostalgia of some people for the glorious days of the Austro-Hungarian Empire. The coexistence described by Claude Magris (Magris 1986; Ara and Magris 1991) testifies to the existence of beneficial cross-cultural relations, even if not all social groups were concerned in equal measure. 
My current domicile of Strasbourg also exemplifies the relativeness of the cardinal points. From Berlin, the city is situated to the West, and from Paris to the East. Indeed, I prefer the geographical references. In the past other connotations were employed for the contentious Franco-German border, such as the Latin zone versus the Germanic zone, or the civilized world versus the barbarian world, which suggested the superiority of one culture. Although Strasbourg experienced its heyday during Rhenish humanism - long before the Thirty Years' War annihilated landscapes, humans, and spirits - nationalisms constructed an otherness.

Perhaps I am focusing too much on my continent. In other areas of the world the same questions are raised. At the age of fourteen, I spent two months in Hawaii, which for many people is an island paradise incarnate. Surrounded by the ocean, I instead suffered from the fact that I felt enclosed, as though by the Berlin Wall. Berlin could be seen as a black island in the red ocean. In Hawaii, despite geopolitical lacunae, the East-west paradigm continues to be employed in writing the cultural politics of the island. Although Pacific peoples were inserted into an "East" and "West" geopolitical framework that represented Asia and the United States, respectively, and implicated "oriental" and "occidental" constructs, their subjectivity beyond these concepts was negated.

\section{AMBIVALENCE OF THE TERM}

I have also given a brief summary of my life for methodological reasons. Influenced by German, French, and English scholars, I cannot pretend to represent, for example, a Balkan point of view. In any case, I am inclined to question why Todorova declares the death of Central Europe (2000: 219). As a Bulgarian scholar, does she not insist on the negative facets of Central Europe that tried to exclude the Balkans? Referring to Milan Kundera, I also have to question whether he reflects a particular Czech vision of Central Europe that, thanks to the celebrity of this author, greatly influenced American research.

Central Europe is marked by the openness of its borders (Krasinski 1988: 38). Although one can agree with the thesis that Central Europe demonstrates the irrelevance of the East-West polarity because it is part of both (Vidmar - Horvat and Delanty 2008: 207), it is necessary to analyze why and at what moment inclusive or exclusive interpretations are used. Depending on the periods, Ljubljana, for instance, has defined itself with an East West paradigm in equating the Balkans with orientalism; it has also pointed out its cultural diversity of Slavic, Germanic, and Latin influences. Like Europe as a whole, the "macroregion" of Central Europe (Hroch 2000: 21) is not a homogenous entity. At a summit in Brussels on 1 March 2009, Hungary's demand that 160 billion euros be given to Eastern and Central European countries was even rejected by Central European countries such as Poland and the Czech Republic. The participants in the summit justified their refusal by the desire to distinguish the economic situation in each central and Eastern European 
country. To quote German Chancellor Angela Merkel, "You cannot compare Slovenia and Slovakia to Hungary" (Die Welt, 1 March 2009).

Central Europe's history is characterized by two tendencies: the idea of unity, which implies a homogenous region, and resistance to these efforts and the struggle for the autonomy of the peoples living in Central Europe. These antagonistic tensions led to the fragility of political consensus in this geographic area (Stirk 1994: 1). The weakness of political stability is evident in the Balkans, where the occupying powers were seen as an alien element because the multiethnic and cross-cultural landscape was not chosen voluntarily, but imposed by empires. Nationalism was prevalent within these young nations with strong primordial roots whose desire for nation-building was hampered by foreign powers, but whose cultural identity was strong enough to by and large avoid assimilation and integration in a supranational system (Ivanov 1996: 40).

As Jacques Le Rider writes in his book La Mitteleuropa, the historical and geopolitical notion of Central Europe does not correspond to a defined geographical reality. It has vague and varying outlines according to changing situations. Depending on the era, the term had different significations. In the function of the political or economic interest of the author, the concept of Central Europe included different political systems and collectives (Le Rider 1994: 3). For this reason the term "Central Europe is an ambiguous notion. It evokes the memory of nationalism and imperialism as well as the peaceful cohabitation of nations and cultural transfers transcending national identities, but too often at the cost of small nations" (Le Rider 2008: 158).

Despite many arguments by geographers since the Congress of Vienna about what was part of Central Europe and which territories were excluded, a geographical demarcation is not appropriate. "The location of Central Europe in terms of the ill-defined divide between West and East, one that moreover tended to shift during the course of history, was by no means fully clear and has been, indeed, the subject of several debates" (Lewis 1994: 7).

Therefore it seems to be more convenient to opt for another criterion - like the subjective desire in Renan's sense - to determine what belongs to Central Europe.

Otherness even within Central Europe was constructed by separate trajectories and incompatible developments, as Jenő Szücs has convincingly described in the example of the evolution of medieval feudalism. Other borders forming mental maps of Central Europe were the borders of the Empire of Charlemagne, which separated Christian Europe from the Slavs in the East, and the borders drawn by the reformation and counter-reformation of the sixteenth century. Moreover, the borders between the Latin West and Orthodox East, or between Christendom and Islam, have to be considered (Geiss 1996: 8). The old borders influenced the social, cultural, and political life of the peoples living between them and were a marker of differences. The impact of these invisible borders can be seen even in our days, and provides arguments for excluding those from Central Europe that are considered as Others, such as the Balkans. 


\section{HISTORICAL CONCEPTS OF CENTRAL EUROPE}

It is striking that the first ideas of Central Europe were pronounced by Austrians and Germans, who seemed to have many interests in a construct of Central Europe. "Central Europe" as a geopolitical entity emerged at the time of the Congress of Vienna in the context of Metternich's vision of a political balance of powers between the Western powers, Britain and France, and the Eastern power, Russia. Central Europe, under the dominant Habsburg Empire, was viewed as the guarantor of the balance of powers both in terms of international politics as well as in a cultural sense (Görtemaker 2002).

Moreover, the concept of Mitteleuropa is closely connected to German nation-building and identity construction. In the debates about Germany's future borders, the notion of Mitteleuropa was proposed as one possible configuration to ease the tensions between Prussia and Austria and to provide an answer to the German question of grossdeutsch or kleindeutsch (Strath 2008: 172). However, as long as the extent of the German Reich was undecided, the form of Central Europe could be imagined in different manners as well.

One of the proponents of the concept of Mitteleuropa in pre-revolutionary Germany was the liberal economist Friedrich List, whose vision was the creation of a political economy favored by a strong nation-state. His concept included an area from the Baltic and the North Sea to the Mediterranean and the Black Sea. He advocated the whole of Central Europe as a free-trade zone for the fair and free exchange of agricultural products, raw materials, and manufactured goods among the region's developing nation-states (List 1883). The claim was that Germany was placed in the center of Europe, and therefore should play a central role in its economic and thus also political affairs. List's perception, however, was not built on race and ethnicity, but based on a national economy and political democracy rather than the Volk in an ethnic sense (Strath 2008: 176). Nevertheless, this was not an acceptable proposal for other Western states, namely France and Great Britain, which felt threatened by such a concentration of power. Moreover, Prussia was also not interested in a customs union with the empire (Stirk 1994: 6).

At the same time, František Palacký publicized the idea of a Danube Federation, which in turn excluded German regions to limit the influence of Germans in Central Europe. Because of the power structure of that time, this concept did not have any success until the defeat of Germany in the First World War. The interwar ideas of Central Europe, on the other hand, mainly emanated from Eastern Europeans such as Tomáš Masaryk, who integrated the ideas of Palacký.

At the beginning of the First World War the liberal thinker Friedrich Naumann published his book Mitteleuropa, in which he defined Central Europe as a political and economic body from the North Sea to the Alps, and then down to the Adriatic and the Danube Valley (Naumann 1964). In the first version of his plan he excluded Romania, Bulgaria, Serbia, and Greece, but also Switzerland and the Netherlands. He advocated a customs union and confederate system in which all nationalities would be independent 
and protected (Brechtefeld 1996: 45). Although Naumann thought that Germany would dominate the confederation culturally and economically, he wanted to visualize Mitteleuropa not only for the Germans but for all the different nations in this area. He was of the opinion that Central Europe was unimaginable without its diversity of nationalities and religions (Strath 2008: 182), which provoked the bitter criticism by pan-German associations (Stirk 1994: 14).

The First World War changed the map of Europe. Hence Naumann's concept of a reconciliation of the national and the social, the state and the economy, and German and Slavic populations failed. Germany was not in a position to propose Naumann's concept of Central Europe. The reconstitution of Poland and the creation of Czechoslovakia and Yugoslavia on the one hand and, on the other hand, the large territorial losses of Austria and Hungary, which reduced their political weight to those of small states, reshuffled Central Europe's geopolitics. Regarding postwar nationalism and territorial claims, Central Europe became a utopia of a vanished era. "What was East, what West in a landmass whose political divisions had been utterly and unrecognizable remade within a single lifetime?" (Judt 1991: 25).

It is a tragedy that in the 1930s Central Europe became a central analytical tool in new imaginary representations of national unity. The one-sided concepts were now related to racial and ethnic discourses that did not accept any equality of the different states in Central Europe. The Second World War proved at the military and political level that Central Europe could not be a buffer zone between the West and the East. Nazi Germany had discredited any idea of Mitteleuropa. With the eradication of the Jews by the German occupants and the expulsion of the German residents of Central Europe after the Second World War, two large communities disappeared from this area. This is why it seemed to make no sense to revive the idea of Central Europe (Stirk 1994: 21). After the formation of the Iron curtain, there was no place left for a transition zone like Central Europe.

\section{CENTRAL EUROPE IN THE VIEW OF DISSIDENTS}

It was only in the 1980s that dissidents from Hungary, Poland, and the former Czechoslovakia took up the term "Central Europe," but in new sense. Timothy Garton Ash remarks that these concepts omitted divided Germany. With nostalgia, the dissidents looked backward to the Austro-Hungarian monarchy and forward to revising the order imposed by Yalta (Ash 1994: 2).

The following papers - Jenő Szűcs's “The Three Historic Regions of Europe, An Outline" (published in Hungarian in 1983), Czesław Miłosz’s "The Witness of Poetry," and Milan Kundera's "The Tragedy of Central Europe" (first published in French under the title "Un Occident kidnappé ou la tragédie de l'Europe centrale" [A Kidnapped West or the Tragedy of Central Europe]) - had in common the constituting of the otherness of 
Russia. In the representation of these dissidents, Central Europe was distinguished from what was often considered a homogeneous Soviet bloc. Russia was then marked as the one that was qualitatively different from Central Europe. There were some nuances in the manner of otherness, but Russia was blamed as the one that hampered the development of Central Europe. Nonetheless, in cultural terms East-Central Europe belonged to the West, which in Kundera's bitter words was a "West that, kidnapped, displaced and brainwashed, nevertheless insists on defending its own identity" (Kundera 1984: 134). Although the Soviet Union had "kidnapped" East-Central Europe through Yalta, the West had forgotten the tragic fate of the other half of Europe. Central Europe and Eastern Europe had vanished in the collective memory of those states that tackled the construction of the European Union as if they represented all of Europe. That this "collective cultural amnesia" (Judt 1991: 27) had been observed in countries like France and Italy with strong communist influences after the Second World War might not amaze very many, but even West Berliners forgot their fellow countrymen behind the Iron Curtain as though the wall were not a reminder of a crime against humanity.

Nevertheless, Eastern dissidents did not meet much response when they argued that Central Europe was part of Europe itself, which is why Europe could not be whole without this part (Kundera 1984: 16). Apart from the desire for liberation from the Soviet Union, there was not, however, any concrete political project. According to Kundera, Central Europe was "a culture or a destiny," and according to György Konrád it represented "nostalgia and utopia” (Konrád 1986: 86).

The dissidents hoped to fight against "the spirit of Yalta," standing for a military solution to social questions (Konrád 1985: 65), in reviving the idea of Central Europe as a zone of mediation and transition, the center in a metaphoric and symbolic sense. They considered Central Europe to be a sort of bridge between the East and the West. The West-east antagonism of the Cold War was supposed to be replaced by a republic-based understanding of politics. The dissidents did not link the topic of Central Europe to the stage of development in Western countries, but instead reverted to their own traditions and representations. They used the recourse of symbols that were rooted in the cultural memory of these countries. In these arguments, special national features were shared by an emphasis on the existence of common points among Central Europeans. The intention was to underpin their values, basic beliefs, and claims to verity as well as central ideas of civil society, and define a cultural and normatively charged space by reference to a historical belonging (Schmidt 2001: 17 ff.). The debate about Central Europe was characterized by the interaction of political, cultural, and regional identity as well as the reassessment of space vis-à-vis time. Ideologies are socially constructed interpretations of trueness. In the case discussed here, these interpretations of trueness describe the specificity of Central Europe, a Central European collective idea in reverting to histories that renew collective memory, remind, and create symbols and mythic narratives (Schmidt 2001: 22).

However, support for dissident groups was far lower than should have been shown by 
governments claiming to advocate human rights. Intellectual circles in the West considered gradual reforms of the communist countries to be a real alternative to the capitalist system of the Western world without questioning the official statements (Mayhew 1998: 5). Even when the peoples of Central Europe caused the fall of the Berlin Wall without any assistance from outside, the urge to "return" to Europe did not meet reciprocity in the Western states. Europe seemed to have gotten used to living without Central Europe, which had become a periphery during the Cold War.

Václav Havel tried in vain to promote the idea of Central Europe. In recognizing the efforts of Central European peoples in January 1990, he voiced the idea that Central Europe was a cultural concept in search of realization when he told the Polish Sejm that:

There is before us the real historic chance to fill with something meaningful the great political vacuum that appeared in Central Europe after the break-up of the Habsburg Empire. We have the chance to transfer Central Europe from a phenomenon that has so far been historical and spiritual into a political phenomenon. We have the chance to take a string of European countries that until recently were colonized by the Soviet Union which would be founded on equal rights, and transform them into a definite special body; which would approach Western Europe not as a poor dissident or a helpless, searching amnestied prisoner, but as someone who has something to offer. (Havel 1990: 75)

Havel's idea did not find much support because Central Europe's states were eager to join the European Union. As a result of the enlargement, the political projects of Central Europe have been rendered obsolete.

\section{DREAMING AND WRITING OF A SYMBIOSIS}

Even if the political projects of Central Europe are not viable, I would not agree with Maria Todorova that Central Europe is dead. However, the idea of Central Europe can only survive in the scope of the European Union. Reservations towards Central Europe are not specific to this macroregion. Jacques Le Rider framed skepticism towards Central Europe in the context of a general euro-skepticism. The concept of Central Europe still has relevance in serving as a transition from the Warsaw Pact under the dominance of the Soviet Union to sovereign states within the European Union (Le Rider 2008: 167). How current this question is and how widespread resentments against the bureaucracy of the European Union remain was recently evidenced by the speech of Czech President Václav Klaus in the European Parliament, in which he compared this institution to the former communist system.

In my view, Central Europe can contribute cultural and social concepts to Europe, which is in search of its identity and its cultural bases. In the past, Central Europe has acted as a cultural crossroads for the continent as a whole. It still has the capacity to follow 
these traditions. I am not thinking of the concepts presented earlier because these were very exclusive concepts. The discussion about Central Europe should not be interpreted as an attempt to exclude somebody from Europe. Instead, it proves the existence of several historical belongings. Even if it is impossible to define the limits of Central Europe and other European regions, it is also evident that Central Europe has multiple margins (Rupnik 1990: 40), which have been thresholds from East to West and vice versa.

However, given the democratic deficits and the unequal distribution of wealth in Russia, this country seems to be more distant from Europe than ever since Kundera's paper. Without any norms, no concept would prove its worth. Tolerance, democracy, and liberty are constituent values of European heritage that the Central European countries recognized in joining the EU. Nonetheless, Central Europe also has something to offer, as Václav Havel stated. Reinterpreting the mode of Central Europe makes it possible, for example, to valorize the experiences of cross-cultural and inter-ethnic tolerance and coexistence in Central Europe in the context of the migration of various ethnic groups in these countries (Vidmar - Horvat and Delanty 2008: 214).

I am also thinking of Central Europe's evolution during the last twenty years. In my opinion, Western Europe could benefit from the rich experiences central and Eastern European countries made after the collapse of their communist systems. The transformation processes of that time probably represented even greater changes than the globalizing processes of recent years and may be similar to the restructuring processes expected in the coming years.

In spite of some difficulties and failures, these countries proved to have an amazing adaptability and learning aptitude, which were finally recompensed by entry into the EU only fifteen years after the fall of the Berlin Wall. Their efforts to reform their political, legal, and social institutions merit the compliments of the Western world, which demonstrates less flexibility in facing necessary reforms. The problem is simply that Western people have not yet realized the useful contributions of Central Europe. Nadège Ragaru (2001: 146) complains about the absence of any curiosity in Western states about the other half of Europe. Only a few scholars think that the other part of Europe could be conducive to the debate about the role of the state in the globalized world and about social redistribution in a new economic context.

In this period of financial and economic crisis, recent polls show that people's morale has reached a low. It is true the unemployment rate, instable situations, and precariousness do not contribute to optimism. Our economic and social order will probably have completely changed after restructuring the system. However, in comparison to Central European states, the welfare system is still working well in Western Europe, although one must anticipate cutbacks of social services. The notion of precariousness, however, means something different in Bucharest than in Paris. People behind the Iron curtain lived in an economy of scarcity. It required great flexibility and ingenuity to manage everyday life. These are characteristics we need today, when we are exposed to the greatest financial 
and economic crisis since 1929. It is also a question of the spirit to face changes. Central Europeans have proved to have an extraordinary ability to reorganize their political, social, and economic life. I am therefore convinced that there are some lessons to learn from Central European countries.

After the failure of the communist and "socialist" experiments, I will not advocate an anti-capitalist system like Western intellectuals did it in the 1980s, which made them deaf to the voices of Eastern dissidents. However, perhaps now is the moment when we will also realize the downsides of economic growth to the dream of a symbiosis of Western and Eastern elements in a European society that pursues other goals besides increasing consumption. Both sides must rethink the bases of social links such as the limits of egalitarianism, new definitions of liberty, the limits of economic growth, new solidarities, a re-examination of the paradigm of modernity, and new values in our societies.

\section{REFERENCES}

Ara, Angelo and Claudio Magris

1991 Trieste: Une identité de frontière. Paris: Éditions du Seuil.

Ash, Timothy Garton

1994 Mitteleuropa?. In: Stirk, Peter M. R., Mitteleuropa: History and Prospects. Edinburgh: Edinburgh University Press, 1-21.

Brechtefeld, Jörg

1996 Mitteleuropa and German Politics, 1848 to the Present. London: Macmillan.

Geiss, Imanuel

1996 Frontières et périphérie dansl'Europe moderne et contemporaine. In: Baechler, Christian and Carole Fink (Hrsg.), L'Etablissement des frontières en Europe après les deux guerres mondiales. Bern, Berlin u. Frankfurt am Main: Peter Lang, 3-20.

Görtemaker, Manfred

2002 Geschichte Europas. Stuttgart: Kohlhammer.

Havel, Václav

1994 Allocution prononcée devant la Diète et le Sénat polonais. Varsovie, le 25 janvier 1990. In: L’angoisse de la Liberté. Paris: Éditions de l'aube, 69-78.

Hroch, Miroslav

2000 'Central Europe': The Rise and Fall of an Historical Region. In: Lord, Christopher, Central Europe: Core or Periphery? Copenhagen: Business School Press, 21-34.

Ivanov, Andrey

1996 The Balkans divided: Nationalism, Minorities, and Security. Frankfurt am Main: Peter Lang..

Judt, Tony

1991 The Rediscovery of Central Europe. In: Graubard, Stephen R., Eastern Europe...Central Europe... Europe. Boulder: Westview Press, 23-58. 
Konrád, G.

1986 Der Traum von Mitteleuropa. In: Busek, E. u. G. Wilfinger, Aufbruch nach Europa. Wien: Edition Atelier, 87-97.

Krasinski, Andrej

1988 Mitteleuropa. In: Burmeister, H. P., F. Boldt and G. Meszaros (Hrsg.), Mitteleuropa: Traum oder Trauma. Bremen: Ed. Temmen.

Kundera, Milan

1983 Un occident kidnappé. Le Débat 27 (nov. 1983): 3-22.

1984 The Central European Tragedy. The New York Review of Books, April 26th: 33-38.

Le Rider, Jaques

1994 La Mitteleuropa. Paris: PUF.

2008 Mitteleuropa, Zentraleuropa, Mittelosteuropa. A Mental Map of Central Europe. European Journal of Social Theory 11 (2) :155-169.

Lewis, Paul G.

1994 Central Europe since 1945. New York: Longman Publishing Group.

List, Friedrich

$1883^{7}$ Das nationale System der politischen Oekonomie. Stuttgart: Cotta.

Magris, Claudio

1986 Danube. Paris: Éditions Gallimard.

Mayhew, Alan

1998 Recreating Europe: The European Union's Policy towards Central and Eastern Europe. Cambridge University Press.

Milosz, Czeslaw

1983 The Witness of Poetry. Harvard University Press.

Naumann, Friedrich

1964 Werke 4. Schriften zum Parteiwesen und zum Mitteleuropaproblem. (Nipperdey, Thomas und Wolfgang Schieder, Hrsg.). Köln, Opladen: Westdeutscher Verlag.

Ragaru, Nadège

2001 Démocratisation et démocraties est-européennes: le miroir brisé. Révue internationale et stratégique 41.

Rupnik, Jaques

1990 L'autre Europe: Crise et fin du communisme. Paris: Éditions Odile Jacob.

Schmidt, Rainer

2001 Die Wiedergeburt der Mitte Europas: Politisches Denken jenseits von Ost und West. Berlin: Akademie Verlag.

Stirk, Peter

1994 The Idea of Mitteleuropa. In: Stirk, Peter M. R., Mitteleuropa: History and Prospects. Edinburgh: Edinburgh University Press, 1-35. 
Strath, Bo

2008 Mitteleuropa: From List to Naumann. European Journal of Social Theory 11 (2): 171-183.

Szücs, Jenõ

1985 Les Trois Europes. Paris: L’Harmattan.

Todorova, Maria

2000 Isn't Central Europe Dead? A Response to Iver Neumann's Forgetting the Central Europe of the 1980s'. In Lord, Christopher, Central Europe: Core or Periphery? Copenhagen: Business School Press, 219-231.

Vidmar - Horvat, Ksenija and Gerard Delanty

2008 Mitteleuropa and the European Heritage. European Journal of Social Theory 11 (2): 203-218.

Online

http://www.ena.lu/address_given_vaclav_havel_polish_sejm_senate_warsaw_25_january_1990-020006831. html

http://www.welt.de/wirtschaft/article3298416/EU-Gipfel-laesst-Traum-von-Osteuropa-Hilfe-platzen.html

\section{SREDNJA EVROPA \\ KOT PREHODNO OBMOČJE MED ZAHODOM IN VZHODOM}

$V$ članku so predstavljeni različni koncepti srednje Evrope, ki potrjujejo nezmožnost, da bi definirali njen geografski in kulturni prostor. Najprej avtorica s tremi geografskimi lokacijami pokaže, kako poljubna sta zahod in vzhod. Vnadaljevanju so poudarjeni zgodovinski koncepti srednje Evrope in nekaj kulturnih konceptov disidentov iz 80. let preteklega stoletja. Na koncu je razprava o predlogih, ki omogočajo sožitje zahoda in vzhoda kot prehodnega območja $v$ srednji Evropi.

Zgodovinski in geopolitični pomen srednje Evrope ne ustreza kaki opredeljeni geografski realnosti. Izraz ima različne pomene, odvisno od obdobja, političnih in ekonomskih interesov. Zaradi tega je izraz srednja Evropa nejasen, kar spodbuja spomin na nacionalizem in imperializem, a tudi na medkulturno in mirno sožitje.

"Srednja Evropa je geopolitična celota, nastala v času Dunajskega kongresa v okviru Metternichovega pogleda na politično ravnotežje moči med zahodnimi silami. Koncept Mitteleuropa je prav tako tesno povezan z graditvijo nemške nacije in ustvarjanjem njene identitete. Dokler ni bila določena razsežnost nemškega rajha, si je bilo mogoče obliko srednje Evrope zamišljati na različne načine.

Zaradi odvisnosti od razmerij moči v posamičnih obdobjih so propadli različni koncepti srednje Evrope, ki so jih oblikovali Friedrich List, František Palacky in Friedrich Naumann. Po veliki vojni je srednja Evropa postala utopija zginule dobe. Na vojaški in politični ravni je druga svetovna vojna dokazala, da srednja Evropa ne more biti blažilno območje med zahodom in vzhodom. Nacistična Nemčija je razvrednotila vsakršno zamisel o Mitteleuropi.

Šelev 80. letih preteklega stoletja so disidenti z Madžarske, Poljske in bivše Češkoslovaške začeli 
znova uporabljati izraz srednja Evropa, vendar v novem pomenu. Spise Jenöa Szücsa, Czestava Miłosza in Milana Kundere je povezovala konstitucija drugosti Rusije. Disidenti so se borili prosti "jaltskemu duhu", ki je družbena vprašanja želel rešiti z vojaškimi odločitvami. Želeli so oživiti zamisel srednje Evrope kot posredniškega in prehodnega območja, središča v metaforičnem in simboličnem smislu kakor tudi v vlogi mostu med vzhodom in zahodom. Nasprotja med Zahodom in Vzhodom v času hladne vojne naj bi bilo nadomestilo državljansko razumevanje politike. Vendar je bila podpora disidentom precej nižja, kakor bi pričakovali od zahodnih vlad, ki zagovarjajo zaščito človeških pravic.

Zaradi siritve Evropske unije so postali politični projekti srednje Evrope zastareli. Kljub temu je avtorica članka naklonjena misli, da srednja Evropa lahko prispeva h kulturnim in socialnim konceptom Evrope, ki išce svojo identiteto in svoje kulturne temelje. Srednja Evropa bi labko sledila tradiciji kulturnega križišča vse celine.

Zahodna Evropa bi se lahko oprla na bogate izkušnje srednje- in vzhodnoevropskih držav po padcu komunističnih sistemov. Kljub nekaj težavam in zablodam so te dežele pokazale osupljivo prilagodljivost in nadarjenost za učenje, ki sta bili naposled nagrajeni z vstopom v EU le 15 let po padcu berlinskega zidu. Danes potrebujemo lastnosti, ki jih je razkrila največja finančna in gospodarska kriza po letu 1929. Srednjeevropejci so pokazali izjemno zmožnost za reorganizacijo svojega političnega, družbenega in gospodarskega življenja.

Njihovi napori, da preoblikujejo politične, pravne in družbene ustanove si zaslužijo pohvalo zahodnega sveta, ki kaže manj gibkosti pri spoprijemanju z reformami. Morda je zdaj trenutek, ko ob padcu gospodarske rasti sanjamo o sožitju zahodnih in vzhodnih elementov evropske družbe, ki sledijo tudi drugim ciljem in ne le naraščajočemu porabništvu.

Dr. Karen Denni, Université de Strasbourg, karen.denni@gmail.com 